\title{
PENGARUH PEMBERIAN INSENTIF DAN PROMOSI JABATAN TERHADAP SEMANGAT KERJA KARYAWAN PADA PT RAJAWALI NUSINDO CABANG MEDAN
}

\author{
Lokot Muda Harahap \\ Dosen Jurusan Manajemen Fakultas Ekonomi Universitas Negeri Medan
}

\begin{abstract}
Abstrak
Tujuan dari penelitian ini adalah untuk mengetahui pengaruh pemberian insentif dan promosi jabatan terhadap semangat kerja karyawan pada PT Rajawali Nusindo Cabang Medan. Populasi penelitian ini adalah seluruh karyawan pada PT Rajawali Nusindo cabang Medan yang jumlah karyawannya sebanyak 73 orang. Penentuan sampel digunakan dengan teknik total sampling sehingga sampel diambil dari keseluruhan populasi. Data yang digunakan dalam penelitian ini adalah data primer yang diperoleh melalui penyebaran kuesioner pada sampel penelitian yang berjumlah 73 responden. Pengujian yang digunakan adalah uji kualitas data dan uji asumsi klasik. Pengujian hipotesis dilakukan dengan analisis regresi berganda, uji F simultan dan uji parsial. Berdasarkan hasil penelitian diperoleh bahwa secara simultan variabel pemberian insentif dan promosi jabatan berpengaruh terhadap semangat kerja karyawan pada PT Rajawali Nusindo Cabang Medan, dimana nilai Fhitung $>$ F tabel atau 50,220 $>3,128$ dengan level of significant $(\alpha) 0,000<0,005$. Koefesien Determinasi (adjust $R$ square) sebesar 0,578 artinya bahwa besarnya pengaruh pemberian insentif dan promosi jabatan terhadap semangat kerja karyawan PT Rajawali Nusindo Cabang Medan sebesar $58,9 \%$ dan sisanya $41,1 \%$ dipengaruhi oleh faktor variabel lain diluar penelitian. Setelah dianalisis hasil dari penelitian ini adalah terdapat pengaruh yang positif dan signifikan pemberian insentif dan promosi jabatan terhadap semangat kerja karyawan pada PT Rajawali Nusindo Cabang Medan dengan persamaan regresi berganda $\boldsymbol{Y}=$ $7,699+0,473 X_{1}+0,385 X_{2}+e$
\end{abstract}

Kata kunci : Pemberian Insentif, Promosi Jabatan dan Semangat Kerja

\section{PENDAHULUAN}

Sumber daya manusia yang banyak diharapkan dapat membantu keberhasilan dan tercapainya tujuan organisasi. Banyak perbedaan yang mendalami dari setiap individu, membuat para pemimpin perusahaan harus teliti melihatnya, supaya kinerja para karyawan di perusahaan dapat tercapai. Sumber daya manusia harus dikelolah sedemikian rupa dan dikembangkan secara bertahap dan terus menerus supaya hasil yang diperoleh dapat diharapkan dengan sebenarnya. Bermutu bukan hanya berarti pandai saja tetapi memenuhi semua syarat kualitas yang dituntut perkerjaan itu sehingga pekerjaan itu benar-benar dapat diselesaikan sesuai dengan yang direncanakan.

Semangat kerja itu timbul jika didasari oleh beberapa faktor yang menjadi pendukungnya dan semangat kerja selalu membuktikan kinerja perusahaan itu tinggi atau tidak. Demikan pula semangat karyawan di perusahaan, perlu adanya penghargaan berupa pemberian insentif maupun promosi jabatan, karena dengan pemberian penghargaan ini karyawan lebih dihargai, diperhatikan, dan diakui hasil kinerjanya. 
Vol. 10 No. 1 Maret 2015

Dengan adanya sumber daya manusia yang dipergunakan oleh perusahaan perlu adanya sesuatu yang diharapkan oleh para pekerja dari kinerja keras mereka, seperti adanya tambahan yang didapat karena prestasi (insentif), harapan menduduki sebuah tempat kerja yang baik yang dikarenakan kinerja yang baik juga (promosi jabatan). Harapan ini yang perlu diberikan oleh perusahaan demi meningkatkan semangat kerja karyawan demi satu tujuan yang pasti. Dengan meningkatnya semangat kerja ini maka secara otomatis produktivitas perusahaan meningkat dengan baik. Hasil kerja yang baik dan loyalitas karyawan perlu diapresiasi dengan pemberian berbagai penghargaan demi terciptanya kemakmuran perusahaan.

Pemberian insentif sangat memiliki peran yang penting, yaitu bagi perusahaan maupun karyawan itu sendiri. Bagi perusahaan insentif ini dilakukan bertujuan untuk mempertahankan kinerja karyawan, mempertahankan semangat kerja dan memotivasi karyawan yang kurang berprestasi. Selain bagi perusahaan pemberian insentif ini sangat mendorong kinerja karyawan kearah yang lebih tinggi, yang mana pemberian insentif ini bertujuan untuk meningkatkan kesejahteraan karyawan itu sendiri dan ketika kesejahteraan karyawan telah terpenuhi maka kinerja karyawan akan lebih baik dan diharapkan untuk meningkatkan semangat kerjanya.

Dengan demikian pengaruh pemberian insentif ini sangatlah memilki peranan yang begitu besar dalam pengelolaan sumber daya manusia di sebuah perusahaan terutama dalam menyangkut semangat kerja karyawan. Semangat kerja merupakan dorongan yang diberikan melalui pemberian insentif yang sesuai dengan syarat pemberian insentif. Oleh karena itu maka perlu dikembangkan sistem pemberian insentif yang baik dan tepat guna yang akan mendorong setiap individu karyawan dalam meningkatkan kinerja yang baik. Apabila kepuasan dan kenyamanan tercipta dalam setiap diri karyawan, maka akan menciptakan kembali semangat kerja dan tanggung jawab yang baik pula.

Promosi jabatan merupakan sebuah seni yang mendorong karyawan untuk lebih bersemangat dalam melakukan pekerjaan dalam sebuah perusahaan. Perusahaan akan selalu menghargai, memperhatikan ataupun berusaha untuk memberikan rasa nyaman dalam melakukan pekerjaannya. Target promosi jabatan ini lebih difokuskan kepada kepuasan kerja karyawan, dimana karyawan itu lebih dihargai, diperhatikan, dibutuhkan dan diakui kemampuan kinerjanya. Pentingnya promosi jabatan ini akan menyadarkan pemimpin perusahaan untuk tetap menghargai dan mengakui kemampuan kinerja karyawanya dalam meningkatkan semangat kerja, serta terhindar dari masalah masalah yang dapat merugikan karyawan seperti : menurunnya semangat kerja, disiplin menurun, tingkat absensi akan menurun atau bahkan hal yang paling besar adalah terjadi pemogokan kerja bahkan adanya unjuk rasa.

PT Rajawali Nusindo Cabang Medan merupakan sebuah Badan Usaha yang bergerak dibidang distributor Fhiliphs (farmasi, gula, 
alat-alat medis) merupakan perusahaan yang mempekerjakan karyawan untuk menyalurkan barang ke konsumen langsung. PT Rajawali Nusindo Cabang Medan memiliki banyak karyawan, yang umumnya bertugas ntuk mendistribusikan barang ke pihak konsumen. Misi dari perusahaan ini adalah memberdayakan seluruh karyawan sebagai modal utama untuk memberikan mutu layanan terbaik bagi pelanggan dengan kegiatan operasional yang efektif dan efisien, serta menciptakan nilai yang optimal bagi stakeholders.

Semakin banyak jam terbang kerja karyawan semakin besar peluang untuk mendapat insentif maupun promosi jabatan, selain itu juga pasti akan ada roda perputaran jabatan, akan tetapi perputaran jabatan atau pemberian intensif kurang terlaksana dikarenakan oleh beberapa faktor diantaranya, bisa dari pemimpin atau karyawannya itu sendiri. Dengan terjun kelapangan dan mampu bekerja melewati batas dan penuh tekanan akan kerja pastilah mendapatkan imbalan maupun penghargaan yang bagus pula, supaya tujuan utama dari perusahaan itu tercapai dan mampu menjalin kerja sama dalam perusahaan tersebut.

Sebagai perusahaan yang menyerap tenaga kerja dalam skala besar PT Rajawali Nusindo cabang Medan dituntut untuk tetap mempertahankan semangat kerja karyawan karena hal tersebut akan menjaga produktivitas kinerja karyawan terhadap perusahaan. Selain itu juga kepercayaan yang berlebihan yang diberikan oleh perusahaan akan menempatkan posisi kerjanya di satu bagian saja, padahal karyawan tersebut menginginkan sebuah jabatan atau posisi yang baru. Disamping itu juga karyawan selalu risau akan insentif yang berjalan kurang baik, karyawan selalu mengeluh bagaimana semangat bekerja maksimal jika hanya makan gaji saja. Hal ini bisa terjadi bila pimpinan perusahaan selalu berganti, kurangnya komunikasi yang baik, dan berbagai faktor lainnya.

Harus ada perlakuan yang baik bagi karyawan yang diberikan oleh PT Rajawali Nusindo Cabang Medan yang salah satunya adalah pemberian insentif yang merupakan timbal balik dari prestasi yang telah diberikan karyawan kepada perusahaan. Pemberian insentif juga dimaksudkan untuk memotivasi para karyawan yang kurang berprestasi agar meningkatkan hasil kerjanya.

Karyawan selalu ingin merasa puas dalam kinerjanya, selain itu juga karyawan tidak merasa puas jika tidak menduduki sebuah jabatan yang berbeda, dalam artian perlu adanya perusahaan menerapkan perputaran posisi jabatan sesuai bidangnya, selain itu juga karyawan tidak merasa tercukupi kebutuhannya bila hanya mengharapkan gaji saja tanpa adanya tambahan insentif lain dari perusahaan.

Demi terciptanya semangat kerja yang baik, maka perlu PT Rajawali Nusindo cabang Medan memberikan sebuah penghargaan yang baik, dimana pemberian insentif maupun promosi jabatan akan menunjang semangat kerja dan menciptakan produktivitas perusahaan itu sendiri. Bukan hanya memberikan tetapi harus juga memperhatikan sampai ke bagian bawah sekalipun dalam arti pemimpin 
harus melihat karyawan ke bagian yang paling bawah bukan hanya pada bagian tertentu saja. Dengan demikian bisa diketahui semangat karyawan pada PT Rajawali Nusindo Cabang Medan sudah tercapai apa belum setelah insentif dan promosi jabatan itu diberikan.

Pemberian insentif memiliki langkah untuk meningkatkan semangat kerja karyawan dan menjaga stabilitas kenerja dan loyalitas karyawan terhadap perusahaan. Beberapa ahli yang mengemukakan tentang arti atau makna insentif dikemukakan oleh Handoko, (2006:176).

Mengemukakan bahwa : Insentif adalah perangsang yang ditawarkan kepada para karyawan untuk melaksanakan kerja sesuai atau lebih tinggi dari standar-standar yang telah ditetapkan. Pemberian insentif mempunyai tujuan tertentu yang menurut Panggabean (2004: 89) adalah untuk memberikan penghargaan bagi karyawan yang berprestasi, untuk memberikan tanggung jawab dan dorongan kepada karyawan, untuk menjamin bahwa karyawan akan mengerahkan usahanya untuk mencapai tujuan organisasi, untuk mengukur usaha karyawan lewat kinerjanya, untuk meningkatkan produktivitas kerja individu maupun kelompok.

Menurut Rivai (2004:387) mengemukakan bahwa "Salah satu alasan pentingnya pembayaran insentif karena adanya ketidaksesuaian tingkat kompensasi yang dibayarkan kepada eksekutif dengan pekerja lain. Program insentif adalah salah satu cara untuk memungkinkan seluruh pekerja merasakan bersama kemakmuran perusahaan. Selain itu, ada kesadaran yang tumbuh bahwa program pembayaran tradisional seringkali tidak bagus dalam menghubungkan pembayaran dengan kinerja. Jika organisasi mau mencapai inisiatif strategis mereka, maka pembayaran perlu dihubungkan dengan kinerja sedemikian rupa sehingga pembayaran itu mengikuti tujuan karyawan dan tujuan organisasi.

Indikator pemberian insentif yaitu, fasilitas, lama karyawan bekerja, kebutuhan, keadilan dan kelayakan, evaluasi jabatan.

Menurut Siagian (2003:169) Promosi adalah seorang pegawai dipindahkan dari suatu pekerjaan kepekerjaan lain yang tanggung jawabnya lebih besar, tingkatannya lebih besar dalam hirarki jabatan lebih tinggi dan penghasilannya pun lebih besar pula. Indikator Promosi Jabatan yaitu kejujuran, disiplin, prestasi kerja, kerja sama, kecakapan, loyalitas, kepemimpinan, komunikatif, pendidikan.

Menurut Hasibuan (2008:94) mengatakan, semangat kerja adalah keinginan dan kesungguhan seorang mengerjakan pekerjaannya dengan baik serta berdisiplin untuk mencapai prestasi kerja yang maksimal. Indikator semangat kerja yaitu, absensi, kualitas, disiplin, kreatifitas karyawan, sikap dan minat kerja.

\section{METODE PENELITIAN \\ Lokasi Penelitian}

Lokasi penelitian dilaksanakan pada PT Rajawali Nusindo Cabang Medan di Jalan Jend. Gatot Subroto Km.5 No.146 Medan.

\section{Populasi dan Sampel}


Populasi dalam penelitian ini adalah seluruh karyawan pada PT. Rajawali Nusindo cabang Medan yang jumlah karyawannya mencapai 73 orang. Menurut Arikunto (2002:27) sampel adalah sebagai wilayah dan populasi yang diteliti dimana, apabila objeknya kurang dari 100 orang lebih baik diambil seluruhnya sehingga penelitiannya merupakan penelitian populasi. Sebaliknya jika jumlah subjeknya besar dapat diambil antara $10-15 \%$ atau $20-55 \%$.

Berdasarkan pendapat diatas maka penulis menggunakan metode total sampling dengan mengambil sampel yaitu seluruh karyawan yang ada di PT Rajawali Nusindo Cabang Medan sebanyak 73 orang.

\section{Variabel Penelitian dan Definisi Operasional \\ Variabel Penelitian}

Dalam pengujian hipotesis,yang menjadi variable penelitian ini adalah

a. Variabel Independent dalam penelitian ini adalah:

- Pemberian Insentif $\left(\mathrm{X}_{1}\right)$

- Promosi Jabatan $\left(\mathrm{X}_{2}\right)$

b. Variabel Dependen dalam penelitian ini adalah:

- Semangat Kerja (Y)

Defenisi Operasional Variabel

Yang menjadi defenisi operasional masing - masing variable tersebut adalah:

a. Insentif adalah suatu bentuk dorongan finansial kepada karyawan sebagai balas jasa perusahaan kepada karyawan atas prestasi karyawan tersebut. Insentif merupakan sejumlah uang yang di tambahkan pada upah dasar yang di berikan perusahaan kepada karyawan. Indikator yang digunakan untuk mengukur pemberian insentif dalam penelitian ini adalah sebagai berikut: kinerja, lama kerja, senioritas, kebutuhan dan keadilan evaluasi jabatan

b. Promosi adalah apabila seorang pegawai dipindahkan dari suatu pekerjaan kepekerjaan lain yang tanggung jawabnya lebih besar, tingkatannya lebih besar dalam hilarki jabatan lebih tinggi dan penghasilannya pun lebih besar pula. Selain itu juga promosi dapat disimpulkan sebagai perpindahan pekerjaan seseorang dari satu jabatan kejabatan yang lebih tinggi, wewenang dan tanggung jawab semakin besar, status serta pendapatan juga semakin tinggi. Hal mendasar yang membuat perusahaan melakukan promosi adalah untuk mengembangkan potensi karyawan yang sesuai dengan kebutuhan perusahaan. Adapun indikator karyawan yang dapat dipromosikan antara lain: Kejujuran, disiplin, prestasi kerja, kerja sama, kecakapan, loyalitas, kepemimpinan , komunikatif dan pendidikan.

c. Semangat kerja adalah keinginan dan kesungguhan seorang mengerjakan pekerjaannya dengan baik serta berdisiplin untuk mencapai prestasi kerja yang maksimal. Selain itu juga Semangat kerja dapat diartikan sebagai suatu iklim atau suasana kerja yang terdapat di dalam suatu organisasi yang menunjukkan rasa kegairahan di dalam melaksanakan pekerjaan dan mendorong mereka untuk bekerja secara lebih baik dan lebih produktif. Adapun indikator Semangat Kerja Karyawan sebagai berikut : Absensi, Kualitas, Disiplin, Kreativitas Karyawan dan Sikap dan Minat Kerja 


\section{Analisa Regresi Berganda}

Analisa regresi berganda untuk mengetahui pengaruh antara variabel bebas (pemberian insentif dan promosi jabatan) dan variabel terikat (semangat kerja). Persamaan regresi berganda dituliskan dengan rumus sebagai berikut:

$$
\mathrm{Y}=\mathrm{a}+b_{1} X_{1}+b_{2} X_{2}+e
$$

Keterangan :

$$
\begin{aligned}
\mathrm{Y}= & \text { semangat Kerja sebagai } \\
& \text { variabel terikat } \\
X_{1} \quad= & \text { pemberian insentif,sebagai } \\
& \text { variabel bebas } \\
X_{2} \quad= & \text { promosi jabatan,sebagai } \\
& \text { variabel bebas } \\
\mathrm{a} \quad= & \text { konstanta } \\
b_{1}, b_{2}= & \text { koefisien regresi yang } \\
& \text { dicari. }
\end{aligned}
$$

\section{Pengujian Hipotesis \\ Uji simultan}

Uji F yaitu suatu uji untuk mengetahui pengaruh variabel bebas, yaitu Pemberian Insentif $\left(\mathrm{X}_{1}\right)$, Promosi Jabatan $\left(\mathrm{X}_{2}\right)$, secara simultan terhadap variabel terikat, yaitu Semangat Kerja

(Y). Kriteria yang digunakan adalah :

a) $\mathrm{H} 0: \mathrm{b} 1=\mathrm{b} 2=0$, artinya tidak ada pengaruh yang signifikan dari variabel bebas, yaitu Pemberian Insentif $\left(\mathrm{X}_{1}\right)$, Promosi Jabatan $\left(\mathrm{X}_{2}\right)$, secara simultan terhadap variabel terikat, yaitu Semangat Kerja $(\mathrm{Y})$

b) $\mathrm{Ha}: \mathrm{b} 1 \neq \mathrm{b} 2 \neq 0$, artinya ada pengaruh positif yang signifikan dari variabel bebas, yaitu Pemberian Insentif $\left(\mathrm{X}_{1}\right)$, Promosi Jabatan $\left(\mathrm{X}_{2}\right)$, secara simultan terhadap variabel terikat, yaitu Semangat kerja (Y)

Kriteria Pengambilan Keputusan :

Ho diterima jika $\mathrm{F}_{\text {hitung }}<\mathrm{F}_{\text {tabel }}$ pada $\alpha$ $=5 \%$

Ha diterima jika $\mathrm{F}_{\text {hitung }}>\mathrm{F}_{\text {tabel }}$ pada $\alpha$ $=5 \%$

\section{Uji Parsial}

Uji parsial atau koefesien regresi dimaksud untuk memastikan apakah variabel bebas yang terdapat dalam persamaan tersebut secara individu berpengaruh secara signifikan terhadap nilai variabel terikat. Caranya dengan melakukan pengujian terhadap koefisien regresi setiap variabel bebas dengan menggunakan uji t.

Analisis Determinasi $\left(\mathbf{R}^{2}\right)$

Analisis determinasi $\mathrm{R}^{2}$ digunakan untuk mengukur besarnya kontribusi persentase sumbangan variabel bebas yang diteliti $\left(\mathrm{X}_{1}, \mathrm{X}_{2}\right)$ terhadap variabel terikat secara bersama - sama dimana $0 \leq \mathrm{R}^{2} \leq 1$.

\section{HASIL PENELITIAN DAN PEMBAHASAN \\ Hasil Penelitian \\ Analisis Regresi Berganda \\ $\hat{\mathbf{Y}}=\mathbf{a}+\mathbf{b}_{1} \mathbf{X}_{1}+\mathbf{b}_{2} \mathbf{X}_{2}+\mathbf{e}$}

Untuk menguji hipotesis yang menyatakan terdapat pengaruh pemberian insentif $\left(\mathrm{X}_{1}\right)$, promosi jabatan $\left(\mathrm{X}_{2}\right)$ terhadap semangat kerja karyawan (Y) digunakan analisis regresi berganda.

Berdasarkan hasil perhitungan diperoleh hasil persamaan regresi berganda adalah sebagai berikut :

\section{Tabel 1. Hasil Perhitungan Regresi Linear Berganda}

Coefficients $^{\mathrm{a}}$

\begin{tabular}{|l|r|r|r|r|r|}
\hline & \multicolumn{2}{|c|}{$\begin{array}{l}\text { Unstandardized } \\
\text { Coefficients }\end{array}$} & $\begin{array}{c}\text { Standardized } \\
\text { Coefficients }\end{array}$ & & \\
\cline { 2 - 5 } Model & $\mathrm{B}$ & $\begin{array}{c}\text { Std. } \\
\text { Error }\end{array}$ & Beta & $\mathrm{t}$ & Sig. \\
\hline 1 (Constant) & 7.699 & 2.808 & & 2.741 & .008 \\
$\begin{array}{l}\text { Pemberian } \\
\text { Insentif } \\
\begin{array}{l}\text { Promosi } \\
\text { Jabatan }\end{array}\end{array}$ & .473 & .082 & .500 & 5.739 & .000 \\
\hline
\end{tabular}

Sumber: Hasil Pengolahan Data 
Dari data hasil perhitungan di atas dapat dijelaskan sebagai berikut :

$\hat{\mathbf{Y}}=\mathbf{7 , 6 9 9}+\mathbf{0 , 4 7 3} \mathrm{X}_{1}+\mathbf{0 , 3 8 5} \mathrm{X}_{2}+\mathrm{e}$

1. Konstan sebesar7,699 menyakan bahwa jika tidak ada variabel $\mathrm{X}$, maka semangat kerja adalah sebesar 7,699 (asumsi faktor lain konstan).

2. Koefisien regresi variabel $X_{1}$ sebesar 0,473 menyatakan bahwas etiap terjadi peningkatan pemberian insenif akan mempengaruhi semangat kerja sebesar 0.473 (asumsi faktor lain konstan).

3. Koefisien regresi variabel $\mathrm{X}_{2}$ sebesar 0,385 menyatakan bahwa setiap terjadi perubahan promosi jabatan yang baik akan mempengaruhi semangat kerja sebesar 0,385 asumsi faktor lain konstan).

Nilai besaran koefisien regresi $\beta_{1}$ sebesar 0,473 pada penelitian ini dapat diartikan bahwa variabel pemberian insentif $\left(\mathrm{X}_{1}\right)$ berpengaruh positif terhadap semangat kerja karyawan (Y). Hal ini menunjukkan bahwa ketika pemberian insentif mengalami peningkatan sebesar satu satuan, maka semangat kerja karyawan juga akan mengalami peningkatan sebesar 0,473 satuan.

Nilai besaran koefisien regresi $\beta_{2}$ sebesar 0,385 pada penelitian ini dapat diartikan bahwa variabel promosi jabatan $\left(\mathrm{X}_{2}\right)$ berpengaruh positif terhadap semangat kerja karyawan (Y). Hal ini menunjukkan bahwa ketika promosi jabatan mengalami peningkatan sebesar satu satuan, maka semangat kerja karyawan juga akan mengalami peningkatan sebesar 0,385 satuan.

\section{Uji Simultan (Uji F)}

Dari hasil pengujian terhadap uji Anova atau $\mathrm{F}$ test diperoleh nilai $\mathrm{F}$ hitung sebesar 50,220 pada taraf $\alpha=$ 0,05. Adapun $F_{\text {tabel }}$ diperoleh dengan $F_{(1-\alpha)}(2,70)$ adalah 3,128. Dengan demikian Fhitung $>\mathrm{F}$ tabel atau $50,220>3,128$ dengan level of significant $(\alpha) 0,000<0,005$ yang berarti bahwa variabel pemberian insentif dan promosi jabatan secara bersama-sama (simultan) berpengaruh terhadap semangat kerja karyawan pada PT Rajawali Nusindo Cabang Medan.

\section{Uji Parsial (Uji t)}

Adapun metode dalam penentuan $t$ tabel menggunakan ketentuan tingkat signifikan 5\%, dengan $\mathrm{df}=\mathrm{n}-\mathrm{k}-1$ (pada penelitian ini $(\mathrm{df}=73-2-1=70)$, sehingga didapat nilai t tabel sebesar 1,994 .

Tabel 2. Hasil Uji Parsial

\begin{tabular}{|l|c|c|c|c|}
\hline \multicolumn{1}{|c|}{ Variabel } & $\begin{array}{c}\mathbf{t} \\
\text { hitung }\end{array}$ & $\begin{array}{c}\mathbf{t} \\
\text { tabel }\end{array}$ & Signifikan & Keputusan \\
\hline $\begin{array}{l}\text { Pemberian } \\
\text { Insentif }\left(\mathrm{X}_{1}\right)\end{array}$ & 5,739 & 1,994 & 0,000 & Signifikan \\
\hline $\begin{array}{l}\text { Promosi } \\
\text { Jabatan }\left(\mathrm{X}_{2}\right)\end{array}$ & 4,478 & 1,994 & 0,000 & Signifikan \\
\hline
\end{tabular}

Sumber: Hasil Pengolahan Data

1. Pemberian insentif berpengaruh positif dan signifikan terhadap semangat kerja karyawan dengan nilai $\mathrm{t}_{\text {hitung }}=5,739>\mathrm{t}_{\text {tabel }}=1,994$ dan probabilitas 0,000 pada tingkat signifikansi 5\%. Hal ini berarti semakin meningkat pemberian insentif, maka semangat kerja karyawan akan meningkat.

2. Promosi jabatan berpengaruh positif dan signifikan terhadap semangat kerja karyawan dengan nilai $t_{\text {hitung }}=$ $4,478>\mathrm{t}_{\text {tabel }}=1,994$ dan probabilitas 0,000 pada tingkat signifikansi $5 \%$. Hal ini berarti semakin meningkat promosi jabatan yang diberikan perusahaan, maka semakin meningkat semangat kerja karyawan.

\section{Uji R ${ }^{2}$ (R Square)}


Vol. 10 No. 1 Maret 2015

Tabel 3. Hasil Uji R square Model Summary

\begin{tabular}{l|r|r|r|r|}
\hline Model & $\mathrm{R}$ & $\begin{array}{c}\mathrm{R} \\
\text { Square }\end{array}$ & $\begin{array}{c}\text { Adjusted R } \\
\text { Square }\end{array}$ & $\begin{array}{c}\text { Std. Error of } \\
\text { the } \\
\text { Estimate }\end{array}$ \\
\hline 1 & $.768^{\mathrm{a}}$ & .589 & .578 & 3.00754 \\
\hline
\end{tabular}
Sumber: Hasil Pengolahan Data
Angka $\mathrm{R}$ sebesar $\quad 0,768$
menunjukkan bahwa korelasi atau hubungan yang kuat antara variabel independen (pemberian insentif dan promosi jabatan) dengan variabel dependen (semangat kerja karyawan). Koefesien Determinasi ( $\mathrm{R}$ square) sebesar 0,589. Nilai 0,589 ini menunjukkan bahwa variabel semangat kerja $(\mathrm{Y})$ dapat dijelaskan oleh variabel pemberian insentif $\left(\mathrm{X}_{1}\right)$ dan promosi jabatan $\left(\mathrm{X}_{2}\right)$ secara bersama sama sebesar $58,9 \%$ dan sisanya $41,1 \%$ dipengaruhi oleh faktor lain diluar variabel independen.

\section{Pembahasan Hasil Penelitian}

Berdasarkan analisis data penelitian diketahui bahwa sebagian besar responden menyatakan bahwa pemberian insentif termasuk dalam kategori bagus. Pemberian insentif dalam penelitian ini memberikan hasil yang positif dan signifikan terhadap semangat kerja karyawan, artinya jika pemberian insentif semakin tinggi maka akan berpengaruh terhadap semangat kerja karyawan pada PT Rajawali Nusindo Cabang Medan. Hal ini didukung oleh koefisien regresi sebesar 0,473 serta uji signifikansi parsial (uji t) yang menghasilkan nilai $\mathrm{t}$ hitung sebesar 5,739 dengan signifikan 0,000 $(p<0,05)$. Dalam hal ini pemberian insentif berpengaruh positif dan signifikan terhadap semangat kerja karyawan dan diharapkan dengan pemberian insentif ini akan mendorong karyawan untuk lebih giat lagi bekerja dengan tingkat loyalitas karyawan yang meningkat.

Hasil analisa data tentang variabel promosi jabatan diketahui sebagian besar responden menyatakan bahwa promosi jabatan termasuk dalam kategori baik. Promosi jabatan dalam penelitian ini memberikan hasil yang positif dan signifikan terhadap semangat kerja karyawan, artinya jika promosi jabatan semakin tinggi maka akan berpengaruh terhadap semangat kerja karyawan pada PT Rajawali Nusindo Cabang Medan. Hal ini didukung oleh koefisien regresi sebesar 0,385 serta uji signifikansi parsial (uji t) yang menghasilkan nilai $\mathrm{t}$ hitung sebesar 4,478 dengan signifikan $0,000(p<0,05)$. Dalam hal ini promosi jabatan berpengaruh positif dan signifikan terhadap semangat kerja karyawan, dan secara otomatis dengan adanya promosi jabatan ini para karyawan akan berusaha dalam meningkatkan kinerja mereka.

Berdasarkan hasil penelitian terbukti bahwa pemberian insentif dan promosi jabatan memiliki pengaruh yang positif dan signifikan terhadap semangat kerja karyawan dengan koefisien korelasi 0,768 dan nilai adjust $\mathrm{R}$ Square sebesar $58,9 \%$ dan sisanya sebesar $41,1 \%$ dijelaskan oleh faktor lain diluar dari analisa variabel dalam penelitian ini. Selain itu tanda positif pada angka 0,578 menunjukkan adanya arah yang sama dari ketiga variabel tersebut, artinya semakin tinggi tingkat variabel pemberian insentif dan promosi jabatan yang terjadi maka semangat kerja karyawan pada PT Rajawali Nusindo Cabang Medan akan semakin meningkat. 


\begin{abstract}
Secara simultan variabel pemberian insentif dan promosi jabatan berpengaruh signifikan terhadap semangat kerja karyawan dengan uji $\mathrm{F}_{\text {hitung }}(50,220)>\mathrm{F}_{\text {tabel }}$ $(3,128)$ atau Ho ditolak dan $\mathrm{Ha}$ diterima artinya koefisien regresi berganda adalah signifikan. Dengan demikian, pemberian insentif dan promosi jabatan secara simultan berpengaruh signifikan terhadap semangat kerja karyawan pada PT Rajawali Nusindo Cabang Medan.
\end{abstract}

\section{PENUTUP}

\section{KESIMPULAN}

1. Hasil penelitian ini menyatakan pengaruh variabel pemberian Insentif $\left(\mathrm{X}_{1}\right)$ dan promosi jabatan $\left(\mathrm{X}_{2}\right)$ ditunjukkan dari hasil analisis regresi berganda $\hat{\mathbf{Y}}=\mathbf{7 , 6 9 9}+\mathbf{0 , 4 7 3} \mathrm{X}_{\mathbf{1}}+$ $\mathbf{0 , 3 8 5} \mathbf{X}_{2}+$ e. Hal ini memberikan arti bahwa variabel insentif dan promosi jabatan secara bersama sama mempunyai pengaruh yang positif terhadap semangat kerja karyawan. Penelitian ini didukung oleh nilai $\mathrm{R}$ square $\left(\mathrm{R}^{2}\right)=0,589$ atau $58,9 \%$ yang artinya bahwa secara simultan variabel insentif dan promosi jabatan mempunyai pengaruh sebesar $58,9 \%$ terhadap semangat kerja karyawan pada PT Rajawali Nusindo Cabang Medan.

2. Terdapat pengaruh yang positif dan signifikan pemberian insentif dan promosi jabatan terhadap semangat kerja karyawan pada PT Rajawali Nusindo Cabang Medan sebesar $57,8 \%$ dan sisanya sebesar $42,2 \%$ dijelaskan oleh faktor lain diluar dari analisa variabel dalam penelitian ini.

3. Hasil uji hipotesis secara parsial menyatakan bahwa $X_{1}(5,739)$ dan $X_{2}(4,478)>1,994$ atau $t_{\text {hitung }}>t_{\text {tabel }}$ maka hipotesis diterima yang dimana bahwa pemberian insentif dan promosi jabatan memiliki pengaruh yang signifikan terhadap prestasi kerja pada PT Rajawali Nusindo Cabang Medan.

4. Uji hipotesis secara simultan menyatakan bahwa $F_{\text {hitung }}>\mathrm{F}$ tabel atau $50,220>3,128$. Dengan demikian bahwa pemberian insentif dan promosi jabatan berpengaruh positif dan signifikan terhadap semangat kerja karyawan pada PT Rajawali Nusindo Cabang Medan.

\section{DAFTAR PUSTAKA}

Bambang Wahyudi. 2002. Manajemen Sumber Daya Manusia. Bandung: Sulita

Dessler, Gery. 2001. Manajemen Sumberdaya Manusia . Jilid 4. Diterjemahkan oleh Paramitha Rahayu. Jakarta: PT . Prenhallindo.

Faithoni, Abdurrahmat. 2006. Organisasi dan Manajemen Sumber Daya Manusia. Jakarta: PT. Rineka Cipta.

Ghozali, Imam, 2006. Aplikasi Analisis Multivarite dengan SPSS, Cetakan Keempat, Badan Penerbit Universitas Diponegoro, Semarang.

Handoko. 2006. Manajemen personalia \& SDM. Edisi 2. Yogyakarta: BPFE

Hasibuan, Malayu S.P. 2008. Manajemen Sumber Daya Manusia. Jakarta: Bumi Aksara

I Nyoman Tri Purnamayana Putra1 I Nyoman Sudharma. 2012." Pengaruh gaya kepemimpinan partisifatif dan insentif financial terhadap semangat kerja karyawan pada grand komodo dan travel' E-Jurnal Manajemen Universitas Udayana.

Mangkunegara, A.A Anwar Prabu. 2009. Manajemen Sumber 
Daya Manusia. Bandung: PT. Remaja Rosdakarya.

Nitisemito. S. Alex. 2002.

Manajemen Personalia. Edisi

Revisi. Penerbit : Ghalia

Indonesia.

Nugraha Gilang. 2013. "Pengaruh insentif material dan non material terhadap motivasi dan semangat kerja karyawan (Stusi kasus pada karyawan PT. Bank Negara Indonesia Tbk. Kantor Cabang Utama Madura)" . Jurnal Administrasi Bisnis (JAB).V. 06. No.2.

Putri, Syafriana. 2010. "Pengaruh Pengembangan Karir dan Promosi Jabatan Terhadap Semangat Kerja Karyawan Pada Kantor Divisi Regional I PT. TELKOM Medan" (Skripsi). Universitas Sumatera Utara.

Ridwan, 2007. Skala Pengukuran Variabel -Variabel Penelitian. Bandung : Alfabeta

Septiana, Mahalleli Nur. 2011. "Pengaruh Pemberian Insentif Terhadap Semangat Kerja (Kasus Bagian Pemasaran di CV. Jadi Jaya Cemerlang Jaya)". Skripsi. Universitas Riau.

Siagian, Sondang P.2002. Kiat Meningkatkan Produktivitas
Kerja. Cetakan Pertama. Jakarta: Rineka Cipta.

Sinolah. 2012. “Analisis Pelaksanaan Program Promosi Jabatan Dampaknya Terhadap Semangat Kerja Pegawai Pada UPTD Pendidikan Tingkat TK dan SD Kec. Kelemahan". Jurnal otonomi V. 12. no. 04.

Suharsimi Arikunto. 2002. Manajemen Penelitian, edisi Revisi. Jakarta : $\underline{\text { Rineka Cipta }}$

Suhendra, Erdian. 2013. "Pengaruh Pemberian Insentif Terhadap Peningkatan Semangat Kerja Karyawan Bagian Penjualan Sepeda Motor Merek Suzuki Pada PT. Riaujaya Cemerlang Cabang Nangka Pekanbaru". Skripsi. Administrasi Bisnis FISIP Universitas Riau.

Sumarsono, Sony. 2004. Metode Riset SDM. Graha Ilmu. Yogyakarta.

Umar, Husein.2000. Riset Manajemen Sumber Daya Manusia Dalam Organisasi. Edisi Revisi. Gramedia Pustaka Utama

Veithzal Rivai. 2004. Manajemen Sumber Daya Manusia Untuk Perusahaan : Dari Teori Ke Praktik. PT. Raja Grafindo Persada, Jakarta.

http://makalahdanskripsi.blogspot.co m/2008/07/pengaruh-pemberianinsentif-terhadap.html 